\title{
INTEGRATION OF THE OLD AND NEW LAKE SUIGETSU (JAPAN) TERRESTRIAL RADIOCARBON CALIBRATION DATA SETS
}

\author{
Richard A Staff ${ }^{1,2} \cdot$ Gordon Schlolaut $^{3} \cdot$ Christopher Bronk Ramsey $^{1} \cdot$ Fiona Brock $^{1} \bullet$ \\ Charlotte L Bryant ${ }^{4} \cdot$ Hiroyuki Kitagawa ${ }^{5}$ Johannes van der Plicht ${ }^{6,7} \cdot$ Michael H Marshall $^{8} \bullet$ \\ Achim Brauer $^{3} \cdot$ Henry F Lamb ${ }^{8} \cdot$ Rebecca L Payne $^{9} \cdot$ Pavel E Tarasov $^{10} \bullet$ Tsuyoshi Haraguchi ${ }^{11} \bullet$ \\ Katsuya Gotanda ${ }^{12} \cdot$ Hitoshi Yonenobu $^{13} \cdot$ Yusuke Yokoyama $^{14} \cdot$ Takeshi Nakagawa $^{9}$ • \\ Suigetsu 2006 Project Members ${ }^{15}$
}

\begin{abstract}
The varved sediment profile of Lake Suigetsu, central Japan, offers an ideal opportunity from which to derive a terrestrial record of atmospheric radiocarbon across the entire range of the ${ }^{14} \mathrm{C}$ dating method. Previous work by Kitagawa and van der Plicht (1998a,b, 2000) provided such a data set; however, problems with the varve-based age scale of their SG93 sediment core precluded the use of this data set for ${ }^{14} \mathrm{C}$ calibration purposes. Lake Suigetsu was re-cored in summer 2006, with the retrieval of overlapping sediment cores from 4 parallel boreholes enabling complete recovery of the sediment profile for the present "Suigetsu Varves 2006" project (Nakagawa et al. 2012). Over $550{ }^{14} \mathrm{C}$ determinations have been obtained from terrestrial plant macrofossils picked from the latter SG06 composite sediment core, which, coupled with the core's independent varve chronology, provides the only non-reservoir-corrected ${ }^{14} \mathrm{C}$ calibration data set across the ${ }^{14} \mathrm{C}$ dating range.
\end{abstract}

Here, physical matching of archive U-channel sediment from SG93 to the continuous SG06 sediment profile is presented. We show the excellent agreement between the respective projects' ${ }^{14} \mathrm{C}$ data sets, allowing the integration of $243{ }^{14} \mathrm{C}$ determinations from the original SG93 project into a composite Lake Suigetsu ${ }^{14} \mathrm{C}$ calibration data set comprising 808 individual ${ }^{14} \mathrm{C}$ determinations, spanning the last 52,800 cal yr.

\section{INTRODUCTION}

Calibration of radiocarbon data is achieved through comparison of measured ${ }^{14} \mathrm{C}$ determinations with those of samples of known calendar age. Such calibration data sets have been derived from a range of natural paleoenvironmental archives, providing records of atmospheric ${ }^{14} \mathrm{C}$ concentration $\left({ }^{14} \mathrm{C}\right)$ through time. For inclusion in the internationally ratified ${ }^{14} \mathrm{C}$ calibration curve (IntCal13, Reimer et al., this issue), such records must also provide a reliable, independent means of deriving calendar age, against which the ${ }^{14} \mathrm{C}$ determinations can be directly compared. For the last $12,550 \mathrm{cal} \mathrm{yr}$, dendro-

\footnotetext{
${ }^{1}$ Oxford Radiocarbon Accelerator Unit (ORAU), Research Laboratory for Archaeology and the History of Art (RLAHA), University of Oxford, Dyson Perrins Building, South Parks Road, Oxford OX1 3QY, United Kingdom.

${ }^{2}$ Corresponding author. Email: richard.staff@rlaha.ox.ac.uk.

${ }^{3}$ GFZ German Research Center for Geoscience, Section 5.2: Climate Dynamics and Landscape Evolution, Telegrafenberg, D-14473 Potsdam, Germany.

${ }^{4}$ NERC Radiocarbon Facility-East Kilbride, Scottish Universities Environmental Research Centre (SUERC), Scottish Enterprise Technology Park, Rankine Avenue, East Kilbride G75 0QF, United Kingdom.

${ }^{5}$ Graduate School of Environmental Studies, Department of Earth and Environmental Sciences, Nagoya University, Nagoya, Japan.

${ }^{6}$ Centre for Isotope Research, University of Groningen, Groningen, Netherlands.

${ }^{7}$ Faculty of Archaeology, University of Leiden, Leiden, Netherlands.

${ }^{8}$ Institute of Geography and Earth Sciences, Aberystwyth University, Aberystwyth SY23 3DB, United Kingdom.

${ }^{9}$ Department of Geography, University of Newcastle, Newcastle-upon-Tyne NE1 7RU, United Kingdom.

${ }^{10}$ Institute of Geological Sciences, Palaeontology, Freie Universität Berlin, Malteserstrasse 74-100, Building D, 12249 Berlin, Germany.

${ }^{11}$ Graduate School of Sciences, Osaka City University, 3-3-138 Sugimoto, Sumiyoshi-ku, Osaka 558-8585, Japan.

${ }^{12}$ Faculty of Policy Informatics, Chiba University of Commerce, Chiba 272-8512, Japan.

${ }^{13}$ College of Education, Naruto University of Education, Naruto 772-8502, Japan.

${ }^{14}$ Atmosphere and Ocean Research Institute, Department of Earth and Planetary Sciences, University of Tokyo, 5-1-5 Kashiwanoha, Chiba 277-8564, Japan.

${ }^{15}$ For full details, see www.suigetsu.org.
} 
chronologically dated tree-ring data are used for this purpose (IntCal09, Reimer et al. 2009). However, this leaves approximately three quarters of the ${ }^{14} \mathrm{C}$ timescale to be calibrated via alternative marine records, which incorporate additional uncertainties relating to the temporally and spatially variable "marine reservoir effect" (Suess 1955; Mangerud 1972; Stuiver et al. 1986; Reimer and Reimer 2001). Similarly, speleothem data (demonstrated most extensively by Hoffmann et al. 2010 and Southon et al. 2012) require correction (for the dead carbon fraction [DCF] from geologically old carbonate), which, like the marine correction, incorporates additional uncertainties.

Ideally, the ${ }^{14} \mathrm{C}$ calibration curve would be composed of reservoir-free, terrestrial ${ }^{14} \mathrm{C}$ data across the entire range of the method. However, archives that provide such a data set are scarce. In 1998, Kitagawa and van der Plicht (1998a,b, 2000) published the first such record, composed of ${ }^{14} \mathrm{C}$ measurements of terrestrial macrofossils extracted from the varved sediment profile of Lake Suigetsu, Honshu Island, central Japan $\left(35^{\circ} 35^{\prime} \mathrm{N}, 135^{\circ} 53^{\prime} \mathrm{E}\right)$. However, problems with the varve-based calendar age scale of their "SG93" sediment core precluded the widespread adoption of this data set for calibration purposes. These problems resulted primarily from gaps between successively drilled sections of the core, but were also due to uncertainties in the varve counting itself (van der Plicht et al. 2004; Staff et al. 2010). Therefore, Lake Suigetsu was re-cored in 2006, with the retrieval of 4 parallel, overlapping sediment cores this time enabling complete recovery of the sedimentary sequence and the subsequent construction of the new "SG06" composite sediment profile (Nakagawa et al. 2012). Over $550{ }^{14} \mathrm{C}$ determinations have been obtained from terrestrial plant macrofossils picked from SG06, which have been coupled with the core's improved, independent varve chronology (produced through the integration of 2 complementary counting techniques; Marshall et al. 2012; Schlolaut et al. 2012) to provide what is still the only non-reservoir-corrected ${ }^{14} \mathrm{C}$ calibration data set across the entire ${ }^{14} \mathrm{C}$ dating range (Bronk Ramsey et al. 2012).

Although the varve-based age scale of SG93 has been demonstrated to be compromised, the $\sim 250{ }^{14} \mathrm{C}$ determinations from the core remain sound. Therefore, if the 2 sediment cores could be reliably linked, a higher-resolution combined ${ }^{14} \mathrm{C}$ calibration data set could be provided. Here, a physical comparison between the SG93 and SG06 sediment cores is described, enabling such an integration of the respective ${ }^{14} \mathrm{C}$ data sets to be achieved (as has been recently published by Bronk Ramsey et al. 2012).

\section{METHODS}

As with the construction of the composite SG06 sediment profile from the 4 contributing, parallel cores (Nakagawa et al. 2012), archive U-channel sediment from most of the SG93 core sections from which ${ }^{14} \mathrm{C}$ measurements had been previously obtained ("SG93-11" to "SG93-14" and "SG93-20" to "SG93-36") were fitted to the SG06 sediment profile through direct matching of distinct marker horizons (tephras, flood layers, turbidite layers, and other distinct sedimentological structures) between the respective cores. Additional robust matching was made for the intervening SG93 core sections ("SG93-15" to "SG93-19") by microfacies analysis of archive SG93 thin sections using light microscopy. Such thin sections were not available for the other SG93 core sections, however.

The original stratigraphic description of SG93 by H Kitagawa (unpublished) included the depths of distinct marker layers (recorded at 5-mm precision). These layers were, where possible, identified in the archive SG93 sediment and used, along with the visual correlations to SG06 described above, to build a conversion model through which interpolated SG06 composite depth equivalents could be derived for all original SG93 ${ }^{14} \mathrm{C}$ samples. Since the depths of the SG93 distinct marker horizons, as well as the depths from which the SG93 ${ }^{14} \mathrm{C}$ samples were taken, were recorded close to the time of 
the original coring, subsequent expansion/contraction of the archive core material (during the intervening years in storage) is not a problem for the generation of this depth conversion model. Likewise, depth control in SG06 is at 1-mm precision (Nakagawa et al. 2012), as defined by digital photographs of the freshly exposed core section surface taken immediately after extraction from the lake (thereby minimizing subsequent color changes through oxidization and any post-extraction/ storage-related expansion/contraction of the sediment).

\section{RESULTS AND DISCUSSION}

Most SG93 core sections could be matched without difficulty to SG06 through purely visual means, despite the fact that the SG93 sediment had oxidized and therefore lost much of its visible lamination. Only a handful of SG93 core sections were more difficult to place. Figure 1 shows 2 examples of this physical matching process between the respective SG93 and SG06 sediment cores, using both the archive SG93 U-channel material (Figure 1a) and the archive SG93 thin sections (Figure 1b). Table 1 gives the equivalent SG06 composite depths thus derived for the top and bottom of the 26 individual SG93 core sections.

The span of missing sediment between successive SG93 core sections is obtained through subtracting the equivalent SG06 composite core depth of the bottom of a given SG93 core section from that of the top of the underlying section (Table 2). The age span of this gap is given in the varve count and ${ }^{14} \mathrm{C}$ model-derived age scale of Bronk Ramsey et al. (2012; see also Staff et al. 2013; given in $\left.\mathrm{SG} 06_{2012} \mathrm{yr}\right)$.

The gaps between core sections are all $<20 \mathrm{~cm}$, with the exception of that between sections SG9328 and SG93-29, which was a "known problem" to the original authors (Kitagawa and van der Plicht 1998a,b, 2000), who included $300 \mathrm{yr}$ for the $17 \mathrm{~cm}$ of missing sediment estimated. The mean sediment loss between the $26 \mathrm{SG} 93$ core sections was found to be $8.11 \mathrm{~cm}$ (95.4 SG06 $2012 \mathrm{yr}$ ), representing a total loss of $202.8 \mathrm{~cm}$ of sediment and approximately $2386\left(\mathrm{SG}_{2012}\right) \mathrm{yr}$. This is slightly greater than the "not larger than 2000 varve years" attributed by van der Plicht et al. (2004) to the potential cumulative calendar age uncertainties arising from "the possible miscounting of varves and/or hiatuses in the varve sequences" (assessed through comparison of the SG93 ${ }^{14} \mathrm{C}$ data set with those of other long ${ }^{14} \mathrm{C}$ calibration records published at that time). In actuality, it appears that the SG93 varve chronology included a slight over-count compared to the combined varve count and ${ }^{14} \mathrm{C}$ model-derived SG06 2012 chronology of Bronk Ramsey et al. (2012); between the top of SG93 core section SG93-13 and the bottom of SG93 core section SG93-34, 29,102 SG93 vyr were counted, compared to $28,625 \mathrm{SG}_{2012} \mathrm{yr}$ (for the retrieved SG93 sediment, i.e. 31,011 total SG06 $2012 \mathrm{yr}$ minus the $2386 \mathrm{yr}$ of missing sediment from the inter-core section gaps). This is presumably the result of the inclusion of a certain proportion of intra-annual laminations present within the Suigetsu record (see Schlolaut et al. 2012), and represents an over-count of $1.67 \%$ (cf. the " $<1.5 \%$ counting error" estimated by Kitagawa and van der Plicht 1998b based upon duplicated counts of selected SG93 core sections and parallel subsections from specific core depths).

Using the revised core depth/varve age information derived for these SG93 core sections (now lacking the sedimentary gaps that had previously been included, but unrecognized), the SG93 ${ }^{14} \mathrm{C}$ data are demonstrated to be in excellent agreement with those from the SG06 study (Figure 2). Through integrating the 2 cores' data sets, the $565{ }^{14} \mathrm{C}$ determinations from the Suigetsu Varves 2006 project are bolstered by $243 \mathrm{SG} 93{ }^{14} \mathrm{C}$ data points. This significantly enhances the resolution of the combined Lake Suigetsu calibration data set, with 808 individual ${ }^{14} \mathrm{C}$ determinations spanning the last $52,800 \mathrm{cal}$ yr, as recently published by Bronk Ramsey et al. (2012). 


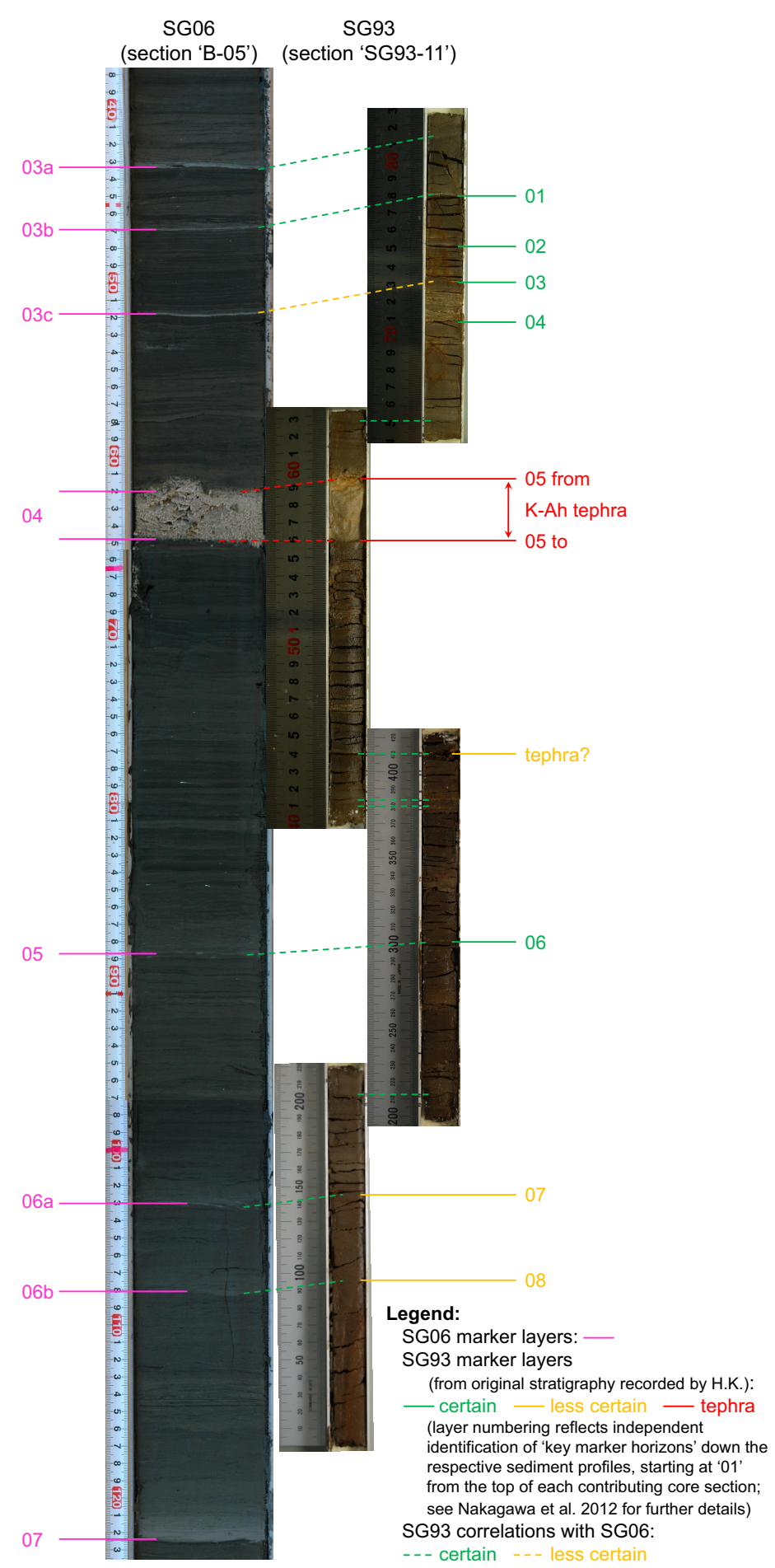

Figure 1a Example matching of an archive SG93 U-channel core section (here, section "SG93-11") on to the fully continuous SG06 composite core (here, section "B-05"). The online version of this figure is presented in full color. 


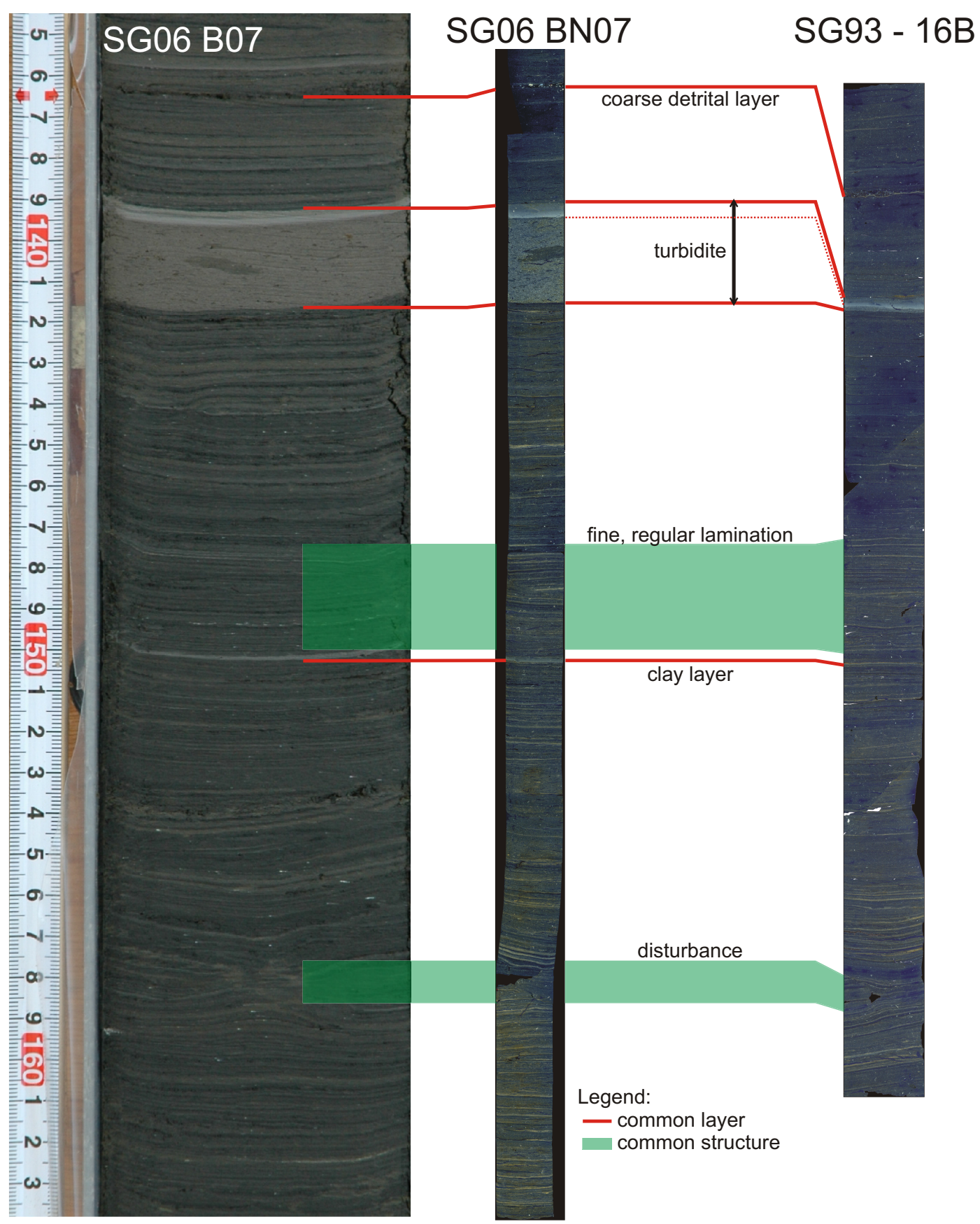

Figure 1b Example matching of an archive SG93 thin section (here, section "SG93-16-B") on to the fully continuous SG06 composite core (here, section "B-07"). The thin-section scans of both core sections (SG06 core section B-07, center, and SG93 core section SG93-16-B, right-hand side) are shown in polarized light against the original SG06 core photograph (core section B-07, left-hand side). The online version of this figure is presented in full color. 
Table 1 Equivalent SG06 composite depth (August 2009 version; Nakagawa et al. 2012) and varve count and ${ }^{14} \mathrm{C}$ model-derived calendar age scale (given in "SG06 2012 yr BP"; Bronk Ramsey et al. 2012; Staff et al. 2013) for the 26 SG93 core sections (SG93-11 to SG93-36) from which ${ }^{14} \mathrm{C}$ determinations were obtained by Kitagawa and van der Plicht (1998a,b, 2000).

\begin{tabular}{|c|c|c|c|c|c|}
\hline $\begin{array}{l}\text { SG93 core } \\
\text { section }\end{array}$ & & $\begin{array}{l}\text { Original SG93 } \\
\text { depth }(\mathrm{cm})\end{array}$ & $\begin{array}{l}\text { Original } \\
\text { SG93 vyr BP }\end{array}$ & $\begin{array}{l}\text { SG06 composite } \\
\text { depth }(\mathrm{cm})\end{array}$ & $\begin{array}{l}\text { Revised } \\
\text { SG06 } 2012 \text { yr BP }\end{array}$ \\
\hline \multirow[t]{2}{*}{ SG93-11 } & Top & 895.0 & $\mathrm{n} / \mathrm{a}$ & 945.0 & $7023 \pm 31$ \\
\hline & Bottom & 987.0 & $\mathrm{n} / \mathrm{a}$ & 1029.6 & $7950 \pm 23$ \\
\hline \multirow[t]{2}{*}{ SG93-12 } & Top & 987.0 & $\mathrm{n} / \mathrm{a}$ & 1037.8 & $8018 \pm 21$ \\
\hline & Bottom & 1045.0 & $\mathrm{n} / \mathrm{a}$ & 1091.8 & $8479 \pm 23$ \\
\hline \multirow{2}{*}{ SG93-13 } & Top & 1042.0 & 8828 & 1095.0 & $8512 \pm 25$ \\
\hline & Bottom & 1133.0 & 9520 & 1182.2 & $9347 \pm 18$ \\
\hline \multirow[t]{2}{*}{ SG93-14 } & Top & 1133.0 & 9520 & 1193.2 & $9431 \pm 16$ \\
\hline & Bottom & 1225.0 & 10,213 & 1280.7 & $10,172 \pm 21$ \\
\hline \multirow[t]{2}{*}{ SG93-15 } & Top & 1225.0 & 10,213 & 1285.1 & $10,210 \pm 20$ \\
\hline & Bottom & 1317.0 & 10,880 & 1374.2 & $11,016 \pm 19$ \\
\hline \multirow[t]{2}{*}{ SG93-16 } & Top & 1317.0 & 10,880 & 1393.4 & $11,203 \pm 13$ \\
\hline & Bottom & 1408.0 & 11,789 & 1474.2 & $11,971 \pm 45$ \\
\hline \multirow[t]{2}{*}{ SG93-17 } & Top & 1408.0 & 11,789 & 1490.6 & $12,138 \pm 45$ \\
\hline & Bottom & 1498.0 & 12,864 & 1579.0 & $13,043 \pm 33$ \\
\hline \multirow[t]{2}{*}{ SG93-18 } & Top & 1498.0 & 12,864 & 1580.6 & $13,062 \pm 33$ \\
\hline & Bottom & 1589.0 & 14,267 & 1672.4 & $14,249 \pm 48$ \\
\hline \multirow[t]{2}{*}{ SG93-19 } & Тор & 1589.0 & 14,267 & 1681.1 & $14,362 \pm 52$ \\
\hline & Bottom & 1680.0 & 15,713 & 1765.1 & $15,703 \pm 55$ \\
\hline \multirow[t]{2}{*}{ SG93-20 } & Top & 1680.0 & 15,713 & 1769.0 & $15,782 \pm 54$ \\
\hline & Bottom & 1771.0 & 17,166 & 1853.5 & $17,626 \pm 56$ \\
\hline \multirow[t]{2}{*}{ SG93-21 } & Тор & 1771.0 & 17,166 & 1858.2 & $17,717 \pm 55$ \\
\hline & Bottom & 1855.0 & 18,572 & 1947.3 & $19,185 \pm 52$ \\
\hline \multirow[t]{2}{*}{ SG93-22 } & Top & 1855.0 & 18,572 & 1950.8 & $19,236 \pm 52$ \\
\hline & Bottom & 1939.0 & 19,992 & 2036.9 & $20,800 \pm 52$ \\
\hline \multirow[t]{2}{*}{ SG93-23 } & Top & 1939.0 & 19,992 & 2035.3 & $20,774 \pm 52$ \\
\hline & Bottom & 2028.0 & 21,566 & 2120.9 & $22,131 \pm 39$ \\
\hline \multirow[t]{2}{*}{ SG93-24 } & Top & 2028.0 & 21,566 & 2123.9 & $22,180 \pm 36$ \\
\hline & Bottom & 2119.0 & 23,088 & 2219.1 & $23,708 \pm 53$ \\
\hline \multirow[t]{2}{*}{ SG93-25 } & Тор & 2119.0 & 23,088 & 2217.9 & $23,686 \pm 53$ \\
\hline & Bottom & 2210.0 & 24,630 & 2316.4 & $25,230 \pm 62$ \\
\hline \multirow[t]{2}{*}{ SG93-26 } & Top & 2210.0 & 24,630 & 2327.7 & $25,419 \pm 60$ \\
\hline & Bottom & 2301.0 & 26,162 & 2427.2 & $27,619 \pm 93$ \\
\hline \multirow[t]{2}{*}{ SG93-27 } & Top & 2301.0 & 26,162 & 2429.5 & $27,619 \pm 93$ \\
\hline & Bottom & 2393.0 & 27,601 & 2526.8 & $28,747 \pm 97$ \\
\hline \multirow[t]{2}{*}{ SG93-28 } & Top & 2393.0 & 27,601 & 2530.5 & $28,801 \pm 98$ \\
\hline & Bottom & 2477.0 & 28,938 & 2609.0 & $29,903 \pm 95$ \\
\hline \multirow[t]{2}{*}{ SG93-29 } & Top & 2494.0 & 29,238 & 2643.5 & $30,009 \pm 94$ \\
\hline & Bottom & 2586.0 & 30,521 & 2729.8 & $31,385 \pm 104$ \\
\hline \multirow[t]{2}{*}{ SG93-30 } & Top & 2586.0 & 30,521 & 2740.1 & $31,611 \pm 103$ \\
\hline & Bottom & 2678.0 & 32,040 & 2830.9 & $33,493 \pm 104$ \\
\hline \multirow[t]{2}{*}{ SG93-31 } & Top & 2678.0 & 32,040 & 2833.3 & $33,544 \pm 104$ \\
\hline & Bottom & 2770.0 & 33,470 & 2918.1 & $35,286 \pm 82$ \\
\hline
\end{tabular}


Table 1 Equivalent SG06 composite depth (August 2009 version; Nakagawa et al. 2012) and varve count and ${ }^{14} \mathrm{C}$ model-derived calendar age scale (given in "SG06 2012 yr BP"; Bronk Ramsey et al. 2012; Staff et al. 2013) for the 26 SG93 core sections (SG93-11 to SG93-36) from which ${ }^{14} \mathrm{C}$ determinations were obtained by Kitagawa and van der Plicht (1998a,b, 2000). (Continued)

\begin{tabular}{llllll}
\hline $\begin{array}{l}\text { SG93 core } \\
\text { section }\end{array}$ & & $\begin{array}{l}\text { Original SG93 } \\
\text { depth }(\mathrm{cm})\end{array}$ & $\begin{array}{l}\text { Original } \\
\text { SG93 vyr BP }\end{array}$ & $\begin{array}{l}\text { SG06 composite } \\
\text { depth }(\mathrm{cm})\end{array}$ & $\begin{array}{l}\text { Revised } \\
\text { SG06 }_{2012} \text { yr BP }\end{array}$ \\
\hline SG93-32 & Top & 2770.0 & 33,470 & 2930.1 & $35,504 \pm 81$ \\
& Bottom & 2862.0 & 34,946 & 3015.3 & $36,964 \pm 87$ \\
SG93-33 & Top & 2862.0 & 34,946 & 3027.0 & $37,150 \pm 86$ \\
& Bottom & 2953.0 & 36,402 & 3123.5 & $38,441 \pm 89$ \\
SG93-34 & Top & 2953.0 & 36,402 & 3134.0 & $38,586 \pm 90$ \\
& Bottom & 3045.0 & 37,930 & 3203.1 & $39,523 \pm 98$ \\
SG93-35 & Top & 3045.0 & n/a & 3217.8 & $39,744 \pm 99$ \\
& Bottom & 3136.0 & n/a & 3297.6 & $40,840 \pm 79$ \\
SG93-36 & Top & 3136.0 & n/a & 3302.0 & $40,901 \pm 78$ \\
& Bottom & 3227.0 & n/a & 3385.1 & $42,098 \pm 84$ \\
\hline
\end{tabular}

Table 2 The length (in $\mathrm{cm}$ ), and equivalent temporal durations (in SG06 2012 yr; Bronk Ramsey et al. 2012; Staff et al. 2013), derived for the missing sediment between successive sections of the SG93 sediment core.

\begin{tabular}{|c|c|c|c|c|c|}
\hline $\begin{array}{l}\text { SG93 inter-core } \\
\text { section gap }\end{array}$ & $\begin{array}{l}\text { Length of } \\
\text { missing } \\
\text { sediment } \\
(\mathrm{cm})\end{array}$ & $\begin{array}{l}\text { Age span } \\
\text { of missing } \\
\text { sediment } \\
\left(\mathrm{SG}_{2012} \mathrm{yr}\right)\end{array}$ & $\begin{array}{l}\text { SG93 inter-core } \\
\text { section gap }\end{array}$ & $\begin{array}{l}\text { Length of } \\
\text { missing } \\
\text { sediment } \\
(\mathrm{cm})\end{array}$ & $\begin{array}{l}\text { Age span } \\
\text { of missing } \\
\text { sediment } \\
\left(\text { SG06 }_{2012} \mathrm{yr}\right)\end{array}$ \\
\hline SG93-11 to SG93-12 & 8.2 & 68 & SG93-24 to SG93-25 & $-1.2^{\mathrm{a}}$ & -22 \\
\hline SG93-12 to SG93-13 & 3.2 & 33 & SG93-25 to SG93-26 & 11.3 & 188 \\
\hline SG93-13 to SG93-14 & 11.0 & 84 & SG93-26 to SG93-27 & 2.3 & $0^{\mathrm{b}}$ \\
\hline SG93-14 to SG93-15 & 4.4 & 37 & SG93-27 to SG93-28 & 3.7 & 54 \\
\hline SG93-15 to SG93-16 & 19.2 & 187 & SG93-28 to SG93-29 & $34.5^{\mathrm{c}}$ & 106 \\
\hline SG93-16 to SG93-17 & 16.4 & 167 & SG93-29 to SG93-30 & 10.3 & 227 \\
\hline SG93-17 to SG93-18 & 1.6 & 19 & SG93-30 to SG93-31 & 2.4 & 51 \\
\hline SG93-18 to SG93-19 & 8.7 & 113 & SG93-31 to SG93-32 & 12.0 & 218 \\
\hline SG93-19 to SG93-20 & 3.9 & 79 & SG93-32 to SG93-33 & 11.7 & 186 \\
\hline SG93-20 to SG93-21 & 4.7 & 91 & SG93-33 to SG93-34 & 10.5 & 144 \\
\hline SG93-21 to SG93-22 & 3.5 & 51 & SG93-34 to SG93-35 & 14.7 & 221 \\
\hline SG93-22 to SG93-23 & $-1.6^{\mathrm{a}}$ & -26 & SG93-35 to SG93-36 & 4.4 & 60 \\
\hline SG93-23 to SG93-24 & 3.0 & 50 & & & \\
\hline
\end{tabular}

${ }^{a}$ Negative differences imply sections of minimal missing material, where expansion of the extracted SG93 core sections is particularly pronounced (up to $3 \%$ upon release from the pressure of the overlying sediment and water column, as cited by Nakagawa et al. 2012).

${ }^{\mathrm{b}} 0$ missing yr, despite $2.3 \mathrm{~cm}$ of missing sediment, because the gap coincides with an instantaneous depositional event layer. ${ }^{\circ} \mathrm{cf} .300 \mathrm{yr}$ inserted by Kitagawa and van der Plicht (1998a,b, 2000) to account for an estimated $17 \mathrm{~cm}$ of "known" missing sediment.

It should be noted that 7 of the original measurements from SG93 were obtained from insect fragments (Kitagawa and van der Plicht 2000). These have been excluded from the composite SG93/ SG06 data set presented here (and published by Bronk Ramsey et al. 2012), since the synthesis of ${ }^{14} \mathrm{C}$ from the atmosphere via the trophic pathway into these organisms is not as direct as is the case with photosynthesizing terrestrial plants - therefore, not representing the contemporaneous $\Delta^{14} \mathrm{C}$ as reliably as the (relatively short-lived) plant macrofossil samples dated. 

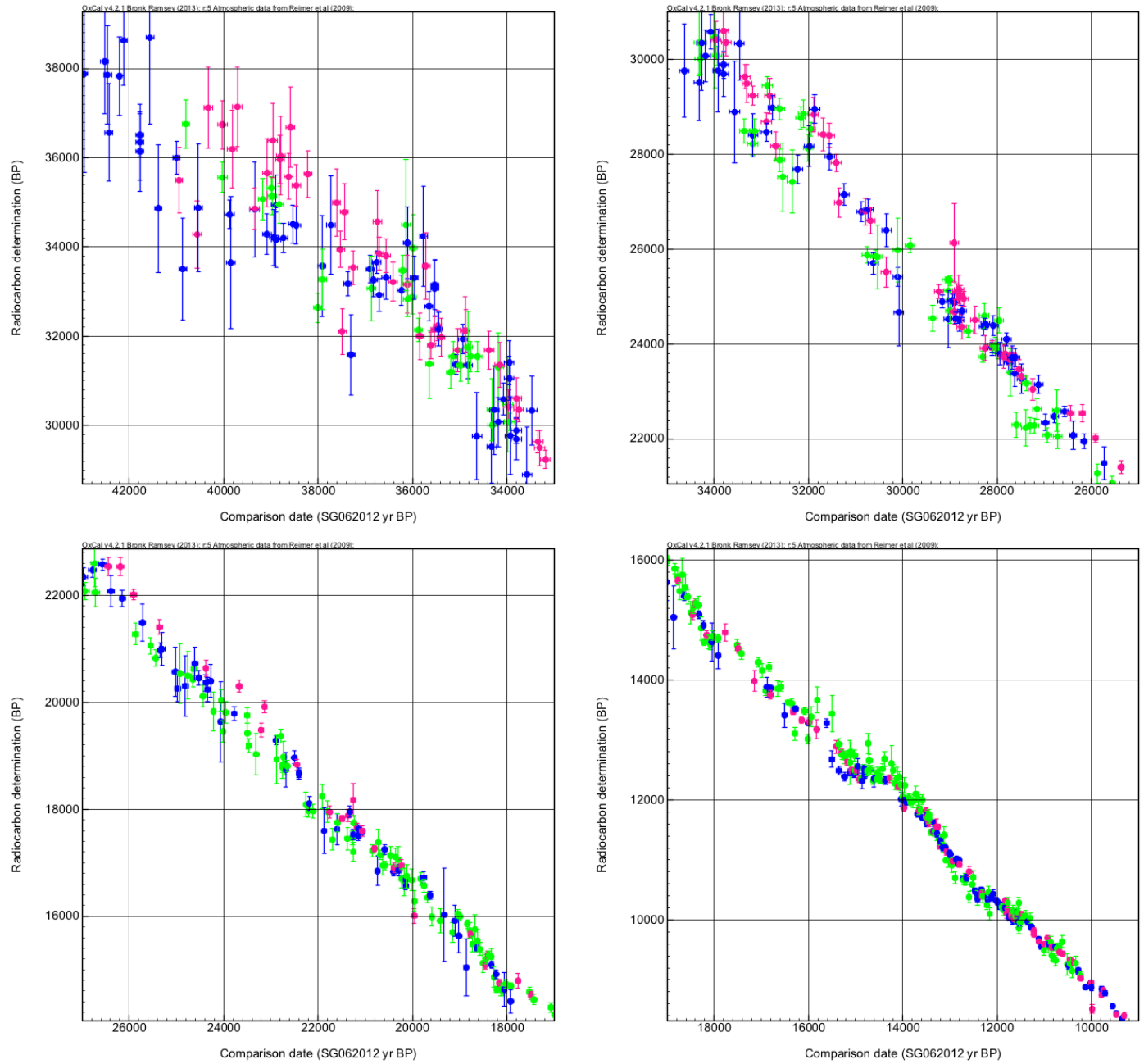

Figure 2 Comparison of SG06 ${ }^{14} \mathrm{C}$ data (produced at Oxford Radiocarbon Accelerator Unit, ORAU, blue data points, and the NERC Radiocarbon Facility-East Kilbride, pink data points) with the revised SG93 data (Centre for Isotope Analysis, University of Groningen, green data points). All data are as presented by Bronk Ramsey et al. (2012). The calibrated age scale is given in SG06 $2012 \mathrm{yr}$ BP (see Bronk Ramsey et al. 2012 and Staff et al. 2013). The online version of this figure is presented in full color.

Also, while the incorporation of the SG93 ${ }^{14} \mathrm{C}$ data does improve the resolution of the (preHolocene) composite ${ }^{14} \mathrm{C}$ calibration data set, these data were not included in the Bayesian modeling to anchor the site's floating varve chronology to the IntCal09 timescale (Staff et al. 2013). The rationale behind this approach was that, while the integration of the ${ }^{14} \mathrm{C}$ data sets of the 2 projects is deemed robust, the depth control with which ${ }^{14} \mathrm{C}$ samples were collected from SG93 (i.e. from 3-cm integrated sampling depths for the uppermost $19.3 \mathrm{~m}$ of the core, corresponding to 20 - to 50 -yr temporal resolution; Kitagawa and van der Plicht 1998b), is not as precise as that for the SG06 samples (taken at $\sim 1$-mm precision; Staff et al. 2011; Nakagawa et al. 2012). Furthermore, the correlation between SG93 and SG06 has greater uncertainty away from the "key correlation horizons" (which exist at intervals of $\sim 5$ to $\sim 30 \mathrm{~cm}$, depending on the stratigraphy of particular core depths and on the differential preservation of the archive SG93 core sections) than does the extremely reliable corre- 
lation between the parallel boreholes of SG06 (Nakagawa et al. 2012). Therefore, while the SG93 data contribute additional information for pre-Holocene ${ }^{14} \mathrm{C}$ calibration, they were not considered appropriate for the high-precision linkage to the decadally resolved IntCal09 tree-ring data set (i.e. the SG93 data were not used for the Bayesian ${ }^{14} \mathrm{C}$ modeling applied to tie the floating Suigetsu varve chronology to the "absolute" IntCal09 timescale; as described by Staff et al. 2013).

\section{CONCLUSION}

Through visual matching of the SG93 and SG06 Lake Suigetsu sediment cores, the ${ }^{14} \mathrm{C}$ determinations from the respective projects have been combined into a single calibration data set comprising $808{ }^{14} \mathrm{C}$ measurements from terrestrial plant macrofossils over 52,800 cal yr. At present, this Lake Suigetsu record provides the only continuous, non-reservoir-corrected data set of atmospheric ${ }^{14} \mathrm{C}$ across the entire range of the ${ }^{14} \mathrm{C}$ dating method, and it contributes a central component of the current version of the international consensus ${ }^{14} \mathrm{C}$ calibration model, IntCal13 (Reimer et al., this issue).

\section{ACKNOWLEDGMENTS}

The authors would like to thank the UK Natural Environment Research Council (NERC; grants: NE/D000289/1, SM/1219.0407/001 and NE/F003048/1), the Deutsche Forschungsgemeinschaft (DFG; grants: BR 2208/7-1 and TA-540/3-1), and the Ministry of Education, Culture, Sports, Science, and Technology (MEXT)-Japan Kakenhi (grant 21101002) for funding of the Suigetsu Varves 2006 project. Additionally, RS would like to thank RLAHA, University of Oxford for personal funding of his DPhil research (upon which the majority of this work is based), and the John Fell Oxford University Press Research Fund for financial support in the writing-up of papers stemming from this work. Finally, we thank Juliane Krenz (GFZ, Potsdam) for assistance with processing of the archive SG93 thin sections.

\section{REFERENCES}

Bronk Ramsey C, Staff RA, Bryant CL, Brock F, Kitagawa $\mathrm{H}$, van der Plicht J, Schlolaut G, Marshall MH, Brauer A, Lamb HF, Payne RL, Tarasov PE, Haraguchi T, Gotanda K, Yonenobu H, Yokoyama Y, Tada R, Nakagawa T. 2012. A complete terrestrial radiocarbon record for 11.2 to $52.8 \mathrm{kyr}$ B.P. Science 338(6105): $370-4$.

Hoffmann DL, Beck JW, Richards DA, Smart PL, Singarayer JS, Ketchmark T, Hawkesworth CJ. 2010. Towards radiocarbon calibration beyond 28 ka using speleothems from the Bahamas. Earth and Planetary Science Letters 289(1-2):1-10.

Kitagawa H, van der Plicht J. 1998a. Atmospheric radiocarbon calibration to $45,000 \mathrm{yr}$ B.P.: Late Glacial fluctuations and cosmogenic isotope production. Science 279(5354):1187-90.

Kitagawa H, van der Plicht J. 1998b. A 40,000-year varve chronology from Lake Suigetsu, Japan: extension of the ${ }^{14} \mathrm{C}$ calibration curve. Radiocarbon 40 (1): 505-15.

Kitagawa H, van der Plicht J. 2000. Atmospheric radiocarbon calibration beyond $11,900 \mathrm{cal}$ BP from Lake Suigetsu laminated sediments. Radiocarbon 42(3): 369-80.
Mangerud J. 1972. Radiocarbon dating of marine shells, including a discussion of apparent age of recent shells from Norway. Boreas 1(2):143-72.

Marshall M, Schlolaut G, Nakagawa T, Lamb H, Brauer A, Staff R, Bronk Ramsey C, Tarasov P, Gotanda K, Haraguchi T, Yokoyama Y, Yonenobu H, Tada R, Suigetsu 2006 Project Members. 2012. A novel approach to varve counting using $\mu \mathrm{XRF}$ and $\mathrm{X}$-radiography in combination with thin-section microscopy, applied to the Late Glacial chronology from Lake Suigetsu, Japan. Quaternary Geochronology 13:70-80.

Nakagawa T, Gotanda K, Haraguchi T, Danhara T, Yonenobu H, Brauer A, Yokoyama Y, Tada R, Takemura K, Staff RA, Payne R, Bronk Ramsey C, Bryant C, Brock F, Schlolaut G, Marshall M, Tarasov P, Lamb H, Suigetsu 2006 Project Members. 2012. SG06, a perfectly continuous and varved sediment core from Lake Suigetsu, Japan: stratigraphy and potential for improving the radiocarbon calibration model and understanding of late Quaternary climate changes. Quaternary Science Reviews 36:164-76.

Reimer PJ, Reimer RW. 2001. A marine reservoir correction database and on-line interface. Radiocarbon 43(2A):461-3. 
Reimer PJ, Baillie MGL, Bard E, Bayliss A, Beck JW, Blackwell PG, Bronk Ramsey C, Buck CE, Burr GS, Edwards RL, Friedrich M, Grootes PM, Guilderson TP, Hajdas I, Heaton TJ, Hogg AG, Hughen KA, Kaiser KF, Kromer B, McCormac FG, Manning SW, Reimer RW, Richards DA, Southon JR, Talamo S, Turney CSM, van der Plicht J, Weyhenmeyer CE. 2009. IntCa109 and Marine09 radiocarbon age calibration curves, 0-50,000 years cal BP. Radiocarbon 51(4): $1111-50$.

Reimer PJ, Bard E, Bayliss A, Beck JW, Blackwell PG, Bronk Ramsey C, Buck CE, Cheng H, Edwards RL, Friedrich M, Grootes PM, Guilderson TP, Haflidason H, Hajdas I, Hatté C, Heaton TJ, Hoffman DL, Hogg AG, Hughen KA, Kaiser KF, Kromer B, Manning SW, Niu M, Reimer RW, Richards DA, Scott EM, Southon JR, Staff RA, Turney CSM, van der Plicht J. 2013. IntCal13 and Marine13 radiocarbon age calibration curves $0-50,000$ years cal BP. Radiocarbon 55(4), this issue.

Schlolaut G, Marshall MH, Brauer A, Nakagawa T, Lamb HF, Staff RA, Bronk Ramsey C, Bryant CL, Brock F, Kossler A, Tarasov PE, Yokoyama Y, Tada R, Haraguchi T, Suigetsu 2006 Project Members. 2012. An automated method for varve interpolation and its application to the Late Glacial chronology from Lake Suigetsu, Japan. Quaternary Geochronology 13:5269.

Southon J, Noronha AL, Cheng H, Edwards RL, Wang Y. 2012. A high-resolution record of atmospheric ${ }^{14} \mathrm{C}$ based on Hulu Cave speleothem H82. Quaternary Science Reviews 33:32-41.

Staff RA, Bronk Ramsey C, Nakagawa T, Suigetsu 2006
Project Members. 2010. A re-analysis of the Lake Suigetsu terrestrial radiocarbon dataset. Nuclear Instruments and Methods in Physics Research B 268(78):960-5.

Staff RA, Bronk Ramsey C, Bryant CL, Brock F, Payne RL, Schlolaut G, Marshall MH, Brauer A, Lamb HF, Tarasov P, Yokoyama Y, Haraguchi T, Gotanda K, Yonenobu H, Nakagawa T, Suigetsu 2006 Project Members. 2011. New ${ }^{14} \mathrm{C}$ determinations from Lake Suigetsu, Japan: 12,000 to 0 cal BP. Radiocarbon 53(3):511-28.

Staff RA, Nakagawa T, Schlolaut G, Marshall MH, Brauer A, Lamb HF, Bronk Ramsey C, Bryant CL, Brock F, Kitagawa H, van der Plicht J, Payne RL, Smith VC, Mark DF, MacLeod A, Blockley SPE, Schwenninger J-L, Tarasov PE, Haraguchi T, Gotanda K, Yonenobu H, Yokoyama Y, Suigetsu 2006 Project Members. 2013. The multiple chronological techniques applied to the Lake Suigetsu (SG06) sediment core. Boreas 42(2)259-66.

Stuiver M, Pearson GW, Braziunas T. 1986. Radiocarbon age calibration of marine samples back to $9000 \mathrm{cal} \mathrm{yr}$ BP. Radiocarbon 28(2B):980-1021.

Suess HE. 1955. Radiocarbon concentration in modern wood. Science 122(3166):415-7.

van der Plicht J, Beck JW, Bard E, Baillie MGL, Blackwell PG, Buck CE, Friedrich M, Guilderson TP, Hughen KA, Kromer B, McCormac FG, Bronk Ramsey C, Reimer PJ, Reimer RW, Remmele S, Richards DA, Southon JR, Stuiver M, Weyhenmeyer CE. 2004. NotCal04-comparison/calibration ${ }^{14} \mathrm{C}$ records 26 50 cal kyr BP. Radiocarbon 46(3):1225-38. 